\title{
PENGARUH KONSUMSI TELUR AYAM RAS TERHADAP KADAR HEMOGLOBIN PADA IBU HAMIL
}

\author{
Dessy Lutfiasari ${ }^{1}$, Galuh Pradian $\mathbf{Y}^{2}$, Vemidella $\mathbf{A}^{3}$ \\ 1,2,3Fakultas Ilmu Kesehatan Universitas Kadiri \\ E-mail: dessylutfiasari@unik-kediri.ac.id, galuhpradian@unik-kediri.ac.id
}

\begin{abstract}
Abstrak
Masa kehamilan sering terjadi anemia fisiologis karena terjadi proses hemodeluasi. Untuk mencegah komplikasi akibat anemia tersebut maka perlu adanya upaya untuk mengurangi anemia yang terjadi pada kehamilan. Salah satu caranya melalui asupan nutrisi yang mengandung zat besi yaitu telur ayam ras. Tujuan dari penelitian ini adalah untuk mengaetahui pengaruh konsumsi telur ayam ras terhadap kadar hemoglobin pada ibu hamil. Metode penelitian yang digunakan adalah pre eksperimental dengan pendekatan pre test post test one grup design. Hasil penelitian menunjukkan bahwa kadar hemoglobin sebelum perlakuan rata-rata 9,21 gr\% dan kadar hemoglobin setelah dilakukan perlakuan yaitu 10,99 gr\%. Hasil uji statistic didapatkan $\mathrm{p}$ value 0,001 dimana $\mathrm{p}$ value $<0,05$ sehingga terhadap pengaruh konsumsi telur ayam ras terhadap kadar hemoglobin ibu hamil. Hasil penelitian dapat dijadikan salah satu alternative dalam upaya menaikkan hemoglobin ibu hamil terutama yang mengalami anemia karena telur mengandung zat besi yang cukup tinggi.
\end{abstract}

Kata kunci : telur ayam ras, kadar hemoglobin

\begin{abstract}
Physiological Anemia often happened in Pregnancy because of hemodilution process. To prevent complications caused by anemia, it is necessary to reduce the incidence rate of anemia in pregnancy. One of the way is comsumed nutrients that contain of iron like a chicken eggs. The purpose of this research is to know the effect of consumption of chicken eggs in the rate of hemoglobin in pregnant women. Pre experimental with pre test post test one group design approach was used as a reaserach method. The results showed that the hemoglobin level before the treatment is $9.21 \mathrm{gr} \%$ and the level of hemoglobin after treatment is $10.99 \mathrm{gr} \%$. The statistic test result obtained P value 0.001 where the $P$ value of $<0.05$ so that the influence of consumption of chicken eggs to the level of hemoglobin pregnancy of pregnant women. Research results can be used as an alternative to raise the hemoglobin of pregnant women, especially those who have anemia because eggs contain high enough iron.
\end{abstract}

Keywords : broiler's chicken egg, hemoglobin level 


\section{LATAR BELAKANG}

Kehamilan merupakan fase yang cukup penting dalam pertumbuhan anak. Gizi ibu dan bayi selama kehamilan akan mempengaruhi pertumbuhan dan perkembangan janin. Oleh karena itu diperlukan perhatian lebih dalam pemenuhan gizi selama kehamilan. Kekurangan gizi pada ibu dan janin dapat mengakibatkan masalah yang serius. Risiko komplikasi pada ibu antara lain anemia, perdarahan, berat badan abnormal, terkena penyakit infeksi. Resiko ini bila dibiarkan secara terus menerus dapat berujung pada kematian.(D. RI, 2010)

Masa kehamilan merupakan suatu permulaan kehidupan baru dari periode pertumbuhan dan perkembangan janin. Keadaan ini berkaitan dengan kesehatan ibu sebelum dan saat hamil, karena sebagai penentu status kesehatan bayinya di masa yang akan datang. Nutrisi adalah salah satu faktor yang mempengaruhi hasil akhir suatu kehamilan. Apabila pemenuhan gizi sebagai pemulihan tidak mencukupi dapat menyebabkan plasenta sebagai media sumber nutrisi tidak mampu menyediakan makanan yang cukup bagi janin. Hal ini dapat menimbulkan berbagai komplikasi dalam kehamilan seperti berat badan lahir bayi rendah, bayi prematur, kelainan bawaan dan anemia pada ibu hamil.(Wiknjosastro, 2010)(Pritasari, Damayanti Didit, 2017)

Pada masa kehamilan, sistem hematologi ibu mengalami perubahan yang signifikan. Salah satunya adalah peningkatan 30-50\% plasma darah, dengan rerata peningkatan 1,5 liter selama masa kehamilan. Hal ini sering disebut sebagai hemodelusi yang terjadi pada usia kehamilan 32-34 minggu. Perubahan lainnya pada sel darah merah, hematokrit dan hemoglobin sepanjang masa kehamilan tidak mengalami kenaikan yang sepadan dengan plasma darah, sehingga seolah - olah hematokrit dan hemoglobin berjurang sehingga terjadi hemodilusi. Untuk itu diperlukan peningkatan pasokan zat besi dan vitamin untuk membuat hemoglobin karena ketika tubuh lebih banyak membutuhkan zat besi dibandingkan dengan yang telah tersedia, maka dapat berpotensi terjadi anemia. (Bakta, 2012)

Menurut World Health Organization (WHO), 40\% kematian di negara berkembang berkaitan dengan terjadinya anemia dalam kehamilan. Kebanyakan anemia dalam kehamilan disebabkan oleh defisiensi besi dan perdarahan akut, bahkan tidak jarang keduanya saling berintaraksi. Anemia dalam kehamilan menjadi masalah utama di Negara berkembang dengan tingkat morbiditas tinggi. Rata - rata kehamilan yang disebabkan karena anemia di usia subur sekitar 72,6\%. Hal ini pula yang terjadi di Indonesia. (Adawiyani, 2013) 
WHO mengatakan bahwa kejadian anemia dalam kehamilan berkisar antara $20 \%$ sampai 89\%. Angka kejadian anemia di Indonesia menunjukkan nilai yang cukup tinggi. Hoo Swie Tjiong menemukan angka anemia dalam kehamilan sebesar 3,8\% (gr/dl) pada trimester I, $13,6 \%$ (g/dl) pada trimester II dan 24,8\% (gr/dl) pada trimester III. (Wiknjosastro, 2010)(Astriana, 2017) Berdasarkan survey kesehatan rumah tangga, sekitar 40,1\%. Terjadi anemia dalam kehamilan. Hasil survey dinas kesehatan Jawa Timur terdapat 42,6\% wanita hamil mengalami anemia. (RISKESDAS, 2018)

Berdasarkan hasil survey pendahuluan yang dilakukan oleh peneliti pada tanggal 20 April 2018 di Kelurahan Pojok wilayah kerja Puskesmas Sukorame data dari bulan Januari - Maret 2018, dari 40 orang ibu hamil, yang memiliki kadar Hb <11gr\% sebanyak 22 orang (55\%) dan yang mempunyai kadar $\mathrm{Hb}>11 \mathrm{gr} \%$ sebanyak 18 orang (45\%). Berdasarkan data tersebut, terlihat bahwa angka kejadian anemia masih tinggi.

Penyebab utama anemia adalah kurang memadainya asupan makanan sumber zat besi, meningkatnya kebutuhan zat besi saat hamil dan menyusui serta kehilangan banyak darah saat persalinan. Anemia disebabkan oleh ketiga faktor yang terjadi secara cepat saat cadangan besi tidak mencukupi peningkatan kebutuhan akan zat besi. Hal ini sering terjadi pada Wanita Usia Subur (WUS) yang tidak memiliki asupan atau cadangan zat yang cukup terhadap kebutuhan dan kehilangan zat besi. (Tanziha, Utama, \& Rosmiati, 2016) Konseling tentang pengaturan diet sangat penting diberikan karena zat besi lebuh mudah diserap dari bahan makanan dibanding dari zat besi oral. Kebutuhan itu dapat dipenuhi dari amakan yang kaya zat besi seperti daging berwarna merah, hati, ikan, telur, sayuran hijau kacang - kacangan, tempe, roti dan sereal. (Pritasari, Damayanti Didit, 2017)

Anemi dalam kehamilan akan memberikan dampak yang bervariasi. Keluhan ringan sampai berat sering dialami wanita saat megalami anemia yang terkadang mengakibatkan efek buruk pada ibu maupun bayi yang akan dilahirkan. Anemia meningkatkan resiko komplikasi pada kehamilan dan persalinan seperti resiko kematian maternal, tingginya angka prematuritas, BBLR dan angka kematian perinatal. Disamping itu, perdarahan antepartum dan postpartum lebih sering dijumpai pada wanita mengalami anemia. WHO menyatakan bahwa 40\% kematian ibu di negara berkembang berkaitan dengan anemia tang terjadi pada masa kehamilan. (Tambunan, 2011)(Tanziha et al., 2016)

Upaya pencegahan dan penanggulangan anemia gizi besi dilaksanakan melalui beberapa program diantaranya berupa pemberian Tablet Tambah Darah (TTD) yang diprioritaskan pada ibu hamil. Hal ini dikarenakan kelompok ibu hamil merupakan kelompok 
rawan yang sangat berpotensi memberikan kontribusi terhadap tingginya Angka Kematian Ibu (AKI). Untuk mencegah anemia gizi pada ibu hamil dilakukan suplementasi TTD dengan daosis pemberian sehari sebanyak satu tablet (60 mg Elemental Iron dan 0,25 mg Asam Folat) berturut - turut minimal 90 hari selama masa kehamilan. (D. RI, 2010) (Pritasari, Damayanti Didit, 2017)

Program pemerintah yang telah dijalankan dalam pendistribusian tablet Fe untuk ibu hamil sudah mendekati target nasional dan kepatuhan ibu dalam mengkonsumsi tablet $\mathrm{Fe}$ sudah cukup baik. Namun kedua hal tersebut masih belum memberi gambaran penurunan kejadian anemia di Indonesia maupun di Provinsi Jawa Timur. Selain suplementasi Tablet Tambah Darah diimbangi dengan konsumsi makanan yang mengandung zat besi. sumber zat besi pada umunya terdapat dalam daging, ayam dan ikan mempunyai ketersediaan biologik tinggi, besi di dalam kacang - kacangan mempunyai ketersedaiaan biologik sedang dan besi dalam sebagian besar sayuran terutama yang mengandung asam oksalat tinggi, seperti bayam mempunyai ketersediaan biologik rendah. Sebaiknya di perhatikan kombinasi makanan sehari - hari yang terdiri atas campuran sumber besi berasal dari hewan dan tumbuh - tumbuhan serta sumber gizi lain yang dapat membantu sumber absorbsi. Menu makanan di Indonesia sebaiknya terdiri atas nasi, daging/ayam/ikan, kacang - kacangan serta sayuran dan buah yang kaya akan vitamin $\mathrm{C}$ serta makanan yang mengandung protein tinggi misalnya telur).(Pritasari, Damayanti Didit, 2017) (Tarwoto, 2015)

Di dalam satu butir telur ayam ras yang utuh mengandung protein, zat besi, seng, selenium, lemak, kolesterol, vitamin A, vitamin D, riboflavin, asam folat, vitamin B12, choline, fosfor dan zinc. Putih telur ayam ras mengandung protein, lemak, vitamin A, riboflavin, asam folat, vitamin B12, fosfor, zat besi, zinc, selenium dan seng. Dan pada kuning telurnya mengandung zat besi, seng, selenium, lemak, kolesterol, vitamin A, vitamin D, riboflavin, asam folat, vitamin B12, choline, fosfor dan zinc. (D. P. RI, 2010)(Indrati \& Gardjito, 2011)

Kandungan gizi telur ayam ras kaya akan protein hewani yang bermutu tinggi. Di dalam telur ayam ras juga mengandung zat yang sangat penting dan cukup tinggi yakni zat besi $6,5 \mathrm{mg}$, seng 6,0 mg dan selenium 5,8 mg. Selain itu, kandungan tambahan dalam telur ayam ras berupa lemak, kolesterol, vitamin A, vitamin D, Riboflavin, asam folat, vitamin B12, choline, pospor dan zink. Telur mengandung zat besi yang cukup baik. Kandungan besi telur ayam ras adalah 6,5 $\mathrm{mg}$ pada telur utuh, 0,2 $\mathrm{mg}$ pada putih telur dan 6,3 mg pada kuning telur. Kandungan zat seng pada telur ayam ras adalah sebesar 6,0 mg telur utuh dan 0,2 $\mathrm{mg}$ 
kuning telur dan putih telur 5,8 mg dan kandungan zat selenium pada telur ayam ras 5,8 mg telur utuh, 1,6 mg putih telur dan 4,2 mg kuning telur. (D. P. RI, 2010) Ibu hamil yang mengkonsumsi telur ayam ras rebus satu butir sehari selama $1-4$ minggu, kenaikan kadar HB akan lebih tinggi dibandingkan yang tidak mengkonsumsi telur ras rebus. (Sugita \& Supiati, n.d.)(Sartika, n.d.)

\section{METODE}

Rancangan penelitian ini menggunakan pre eksperimental design dengan pendekatan one group pretest post test design. Populasi dalam penelitian ini adalah seluruh ibu hamil yang memiliki kadar $\mathrm{Hb}<11$ gr\% di keluruhan Pojok Wilayah kerja Puskesmas Sukorame Kota Kediri. Jumlah sampel yang digunakan berjumlah 15 orang dengan menggunakan Teknik samping purposive sampling dimana ibu yang mengalami alergi telur tidak dimasukkan menjadi responden. Variabel penelitian ini yaitu pemberian telur ayam ras rebus sebanyak 1 telur selama 14 hari sebagai variabel independent dan variabel dependennya yaitu kadar $\mathrm{Hb}$ ibu hamil. Instrumen yang digunakan dalam penelitian ini yaitu lembar observasi untuk mengukur kadar hemoglobin dengan menggunakan stik. Penelitian dilakukan pada bulan November sampai Desember 2018 di keluruhan Pojok Kecamatan Mojoroto Kota Kediri. Analisis data menggunakan uji statistik Wolcoxon Signed Rank dikarenakan hasil uji normalitas data didapatkan berdistribusi tidak normal.

\section{HASIL DAN PEMBAHASAN}

Tabel 1 Kadar Hb ibu hamil sebelum diberikan telur ayam ras

\begin{tabular}{llllllll} 
& $\mathrm{N}$ & Mean & Median & Mode & $\begin{array}{l}\text { Std } \\
\text { Deviation }\end{array}$ & Min & Max \\
\hline $\begin{array}{l}\text { Hb sebelum } \\
\begin{array}{l}\text { konsumsi } \\
\text { telur (gr\%) }\end{array}\end{array}$ & 15 & 9,21 & 9,50 & 9,5 & 1,0842 & 7,0 & 10,4 \\
\hline
\end{tabular}

Tabel 1 menunjukkan bahwa kadar hb sebelum diberikan telur ayam ras rebus rata -rata berkisar 9,21 gr\% dengan $\mathrm{Hb}$ tertinggi yaitu 10,4 gr\% dan $\mathrm{Hb}$ terendah yaitu $7 \mathrm{gr} \%$.

Perubahan hematologi selama kehamilan antara lain dikarenakan terjadinya peningkatan oksigen, perubahan sirkulasi yang makin meningkat terhadap plasenta dan janin serta kebutuhan suplai darah untuk pembesaran uterus sehingga terjadi peningkatan volume darah yaitu peningkatan volume plasma dan sel darah merah.(Bakta, 2012)

Rendahnya kadar $\mathrm{Hb}$ pada wanita hamil sebelum konsumsi telur ayam ras rebus dipengaruhi oleh usia kehamilan ibu, dimana sebanyak 7 orang $(46,7 \%)$ responden dengan usia kehamilan trimester 3. Perubahan sstem sirkulasi darah pada kemailan di trimester I dan 
trimester III akan menyebabkan terjadinya hemodilusi yang akan mencapai puncaknya pada usia kehamilan 32 minggu. (Wiknjosastro, 2010) Dengan demikian dapat disimpulkan bahwa apabila kadar $\mathrm{Hb}$ pada ibu hamil $<11$ gr\% pada trimester I dan III dan $<10,5$ gr\% pada trimester II maka dikatakan bahwa ibu tersebut mengalami anemia dalam kehamilan. Hasil penelitian ini di dukung oleh pendidikan ibu yang masih di tingkat pendidikan dasar yaitu sebanyak 12 orang $(80 \%)$. Rendahnya pendidikan ibu akan berdampak pada rendahnya pengetahuan ibu yang berpangaruh pada kesadaran ibu untuk mendapatkan pelayanan kesehatan. Makin rendah pengetahuan ibu makin sedikit keinginan untuk memanfaatkan pelayanan kesehatan. Oleh sebab itu pendidikan ibu adalah faktor yang cukup berpengaruh terhadap terjadinya anemia. (Tambunan, 2011)

Tingkat pendidikan juga berpengaruh terhadap pengetahuan ibu dan banyaknya informasi yang diterima yaitu kurangnya pengetahuan tentang makanan apa saja yang bisa menaikkan kadar hemoglobin pada ibu hamil. Karena semakin tingginya seseorang menempuh pendidikan maka semakin besar pula pengetahuan dan pengalaman atau informasi yang diperoleh. (Tanziha et al., 2016)

Tabel 2 Kadar $\mathrm{Hb}$ ibu hamil setelah diberikan telur ayam ras

\begin{tabular}{llllllll} 
& $\mathrm{N}$ & Mean & Median & Mode & $\begin{array}{l}\text { Std } \\
\text { Deviation }\end{array}$ & Min & Max \\
\hline $\begin{array}{l}\text { Hb setelah } \\
\text { konsumsi } \\
\text { telur (gr\%) }\end{array}$ & 15 & 10,99 & 11,2 & 11,5 & 0,55 & 10,0 & 11,6 \\
\hline
\end{tabular}

Tabel 2 menunjukkan bahwa kadar hb setelah diberikan telur ayam ras rebus rata -rata berkisar 10,99 gr\% dengan $\mathrm{Hb}$ tertinggi yaitu 11,6 gr\% dan $\mathrm{Hb}$ terendah yaitu $10 \mathrm{gr} \%$.

Kandungan gizi telur ayam ras kaya akan protein yang bermutu tinggi. Rata-rata kadar protein telur adalah 12-16\% dalam satu butir telur yang cukup besar, di dalam telur juga ada kandungan sejenis mineral mikro yang sangat penting, yaitu zat besi, seng, dan selenium. Telur mengandung zat besi yang cukup baik. Di dalam telur ayam ras juga mengandung zat yang sangat penting dan cukup tinggi yakni zat besi $6,5 \mathrm{mg}$, seng $6,0 \mathrm{mg}$ dan selenium 5,8 $\mathrm{mg}$. Selain itu, kandungan tambahan dalam telur ayam ras berupa lemak, kolesterol, vitamin A, vitamin D, Riboflavin, asam folat, vitamin B12, choline, pospor dan zink. Telur mengandung zat besi yang cukup baik. Kandungan besi telur ayam ras adalah $6,5 \mathrm{mg}$ pada telur utuh, 0,2 mg pada putih telur dan $6,3 \mathrm{mg}$ pada kuning telur. Sementara itu, kandungan zat seng pada telur ayam ras adalah sebesar 6,0 mg telur utuh dan $0,2 \mathrm{mg}$ kuning telur dan putih telur 5,8 mg. (D. P. RI, 2010) 
Zat besi adalah komponen dalam perumusan pembentukan hemoglobin yang mempunyai peran penting dalam penyaluran dan penyimpanan oksigen. Defisiensi besi dapat terjadi karena metabolisme energi oleh otot tidak berjalan dengan sempurna akibat kekurangan oksigen. Sedangkan oksigen yang dibutuhkan oleh sel - sel otot ini diangkut oleh zat besi dalam darah yaitu hemoglobin .(Bakta, 2012)

Pada penelitian ini perubahan kadar hemoglobin berkaitan dengan konsumsi telur ayam ras rebus pada ibu hamil. Hal ini didukung oleh keadaan ibu yang tidak bekerja di kantor atau kebanyakan bekerja sebagai ibu rumah tangga sebanyak 13 responden $(86,7 \%)$ sehingga ibu tidak melakukan aktivitas fisik yang berlebihan maka kadar $\mathrm{Hb}$ tidak turun serta usia ibu yang sebanyak 9 orang $(60 \%)$ adalah 20 - 35 tahun yang tergolong usia reproduktif. Faktor yang mempengaruhi terjadinya anemia dalam kehamilan di antaranya adalah usia ibu di bawah 20 tahun dan diatas 35 tahun, sehingga saat usia 20 - 35 tahun pertumbuhan yang ada dan fungsi organ tubuh sudah baik. (Tanziha et al., 2016) Sehingga jika diberikan telur ayam ras rebus yang mengandung zat besi maka akan semakin memperbaiki zat besi dalam tubuh.

\begin{tabular}{lccccccc}
\hline & & \multicolumn{3}{c}{ Kolmogorov-Smirnov $^{\mathrm{a}}$} & \multicolumn{3}{c}{ Shapiro-Wilk } \\
\hline & & Statistic & $\mathrm{D}$ & Sig & Statistic & Df & Sig \\
\hline $\begin{array}{l}\mathrm{Hb} \text { sebelum } \\
\text { telur }\end{array}$ & konsumsi &, 210 & 15 &, 034 &, 871 & 15 &, 035 \\
\hline $\begin{array}{l}\mathrm{Hb} \text { sesudah } \\
\text { telur }\end{array}$ & konsumsi &, 180 & 15 &, 200 &, 878 & 15 &, 045 \\
\hline
\end{tabular}

Hasil uji normalitas data menggunakan Saphiro Wilk didapatkan p value sebesar 0,035 dan 0,045 dimana $\mathrm{p}$ value $<0,05$ sehingga data berdistribusi tidak normal. Sehingga uji statistik yang digunakan yaitu Wilcoxon Signed Rank.

Tabel 3 Pengaruh Pemberian telur ayan ras terhadap kadar Hb Ibu hamil

\begin{tabular}{llccc}
\hline & & N & Mean Rank & $\begin{array}{c}\text { Sum of } \\
\text { Ranks }\end{array}$ \\
\hline Kadar_Hb_Sebelum & Negative Ranks & $0^{\mathrm{a}}$ &, 00 &, 00 \\
Kadar_Hb_Sesudah & Positive Ranks & $15^{\mathrm{b}}$ & 8,00 & 120,00 \\
& Ties & $0^{\mathrm{c}}$ & & \\
& Total & 15 & & \\
\hline
\end{tabular}

\begin{tabular}{lc}
\hline & $\begin{array}{c}\text { Kadar hb sesudah } \\
\text { perlakukan-kadar } \mathrm{Hb} \\
\text { sebelum perlakuan }\end{array}$ \\
\hline $\mathrm{Z}$ & $-3,409^{\mathrm{b}}$ \\
Asymp.Sig.(2-tailed) &, 001 \\
\hline
\end{tabular}

Nilai rata -rata kadar hemoglobin sebelum konsumsi telur ayam ras rebus adalah 9,21 gr\% sehingga termasuk dalam kategori anemia ringan. Nilai rata-rata kadar hemoglobin 
sesudah konsumsi telur ayam ras rebus adalah 10,99 gr\% yang masuk dalam kategori anemia ringan. Nilai selisih rata-rata kadar hemoglobin antara sebelum dan sesudah konsumsi telur ayam ras rebus yaitu 1,78 .

Hasil analisa data data menggunakan uji statistik Wilcoxon Signed Rank didapatkan hasil nilai $\rho$ value $=0,001$ dengan tingkat kepercayaan $95 \%(\alpha=0,05)$ dapat dikatakan bahwa $\rho$ value $<\alpha$ yang berarti $\mathrm{H}_{0}$ ditolak dan $\mathrm{H}_{1}$ diterima maka ada pengaruh konsumsi telur ayam ras rebus terhadap kadar $\mathrm{Hb}$ ibu hamil di Kelurahan Pojok wilayah kerja Puskesmas Sukorame Kota Kediri Tahun 2018.

Defisiensi zat besi dapat terjadi dengan cepat atau lambat. Simpanan zat besi bergantung pada asupan zat besi, kualitas zat besi dalam makanan dan peningkatan atau penghambat absopsi pencernaan makanan yang mengandung zat besi. (Bakta, 2012)

Satu butir telur ayam ras yang utuh mengandung protein, zat besi, seng, selenium, lemak, kolesterol, vitamin A, vitamin D, riboflavin, asam folat, vitamin B12, choline, fosfor dan zinc. Putih telur ayam ras mengandung protein, lemak, vitamin A, riboflavin, asam folat, vitamin B12, fosfor, zat besi, zinc, selenium dan seng. Dan pada kuning telurnya mengandung zat besi, seng, selenium, lemak, kolesterol, vitamin A, vitamin D, riboflavin, asam folat, vitamin B12, choline, fosfor dan zinc. (Indrati \& Gardjito, 2011)

Kandungan gizi telur ayam ras kaya akan protein hewani yang bermutu tinggi. Di dalam telur ayam ras juga mengandung zat yang sangat penting dan cukup tinggi yakni zat besi 6,5 $\mathrm{mg}$, seng 6,0 mg dan selenium 5,8 mg. Selain itu, kandungan tambahan dalam telur ayam ras berupa lemak, kolesterol, vitamin A, vitamin D, Riboflavin, asam folat, vitamin B12, choline, pospor dan zink. Telur mengandung zat besi yang cukup baik. Kandungan besi telur ayam ras adalah 6,5 mg pada telur utuh, 0,2 $\mathrm{mg}$ pada putih telur dan 6,3 $\mathrm{mg}$ pada kuning telur. Kandungan zat seng pada telur ayam ras adalah sebesar 6,0 mg telur utuh dan 0,2 mg kuning telur dan putih telur 5,8 $\mathrm{mg}$ dan kandungan zat selenium pada telur ayam ras 5,8 $\mathrm{mg}$ telur utuh, 1,6 mg putih telur dan 4,2 mg kuning telur . (D. P. RI, 2010)

Penelitian ini didukung oleh penelitian yang dilakukan oleh Sugita tahun 2016 yaitu pada kelompok ibu hamil TM II hasil rata-rata pemeriksaan $\mathrm{Hb}$ sebelum mengkonsumsi tablet $\mathrm{Fe}$ tanpa konsumsi telur ayam ras rebus yaitu 1,0417 gr/dl, dan rata-rata pemeriksaan $\mathrm{Hb}$ setelah mengkonsumsi tablet Fe tanpa konsumsi telur ayam ras rebus yaitu 1,0419. Pada pengolahan data juga menunjukkan perubahan $\mathrm{Hb}$ sebelum dan sesudah mengkonsumsi tablet Fe tanpa konsumsi telur ayam ras rebus pada ibu hamil TM II terjadi peningkatan Hb sebanyak 7 responden dan penurunan sebanyak 8 responden. (Sugita \& Supiati, n.d.) 


\section{KESIMPULAN DAN SARAN}

Kesimpulan dari penelitian ini adalah ada pengaruh konsumsi telur ayam ras terhadap kadar hemoglobin ibu hamil di Kelurahan Pojok Wilayah Kerja Puskesmas Sukorame kota kediri. Dari hasil penelitian dapat disarankan untuk memberikan telur ayam ras sebagai alternatif tambahan nutrisi bagi ibu hamil untuk meningkatkan hemoglobin terutama untuk ibu hamil yang mengalami anemia selain dengan pemberian tablet besi.

\section{UCAPAN TERIMA KASIH}

Ucapan terima kasih kami sampaikan kepada Fakultas Ilmu Kesehatan Universitas Kadiri dan Bidan Wilayah Pojok yang telah banyak membantu terlaksananya penelitian ini.

\section{DAFTAR PUSTAKA}

Adawiyani, R. (2013). Calyptra: Jurnal Ilmiah Mahasiswa Universitas Surabaya Vol.2 No.2 (2013). Jurnal Mahasiswa Universitas Surabaya, 2(2), 1-20.

Astriana, W. (2017). Kejadian Anemia pada Ibu Hamil Ditinjau dari Paritas dan Usia. Jurnal Aisyah : Jurnal Ilmu Kesehatan, 2(2), 123-130. https://doi.org/10.30604/jika.v2i2.57

Bakta, I. made. (2012). Hematologi Klinik Ringkas. jakarta: EGC.

Indrati, R., \& Gardjito, M. (2011). Pendidikan Konsumsi pangan. jakarta: Fajar Interpratama Mandiri. Pritasari, Damayanti Didit, T. L. N. (2017). Gizi dalam daur kehidupan. Jakarta: PPSDM RI.

RI, D. (2010). Bab ii prinsip pengelolaan program kia, 6-16.

RI, D. P. (2010). Seputar Telur : Makanan Bergizi. Jakarta: Departemen Pertanian.

RISKESDAS. (2018). Hasil Utama Riset Kesehatan Dasar. Kementrian Kesehatan Republik Indonesia, 1-100. https://doi.org/1 Desember 2013

Sartika, W. (n.d.). Studi literatur PENGARUH KONSUMSI TELUR REBUS AYAM RAS TERHADAP PENINGKATAN KADAR HEMOGLOBIN (HB) PADA IBU HAMIL TRIMESTER II Windi Sartika, 112-118.

Sugita, \& Supiati. (n.d.). PENGARUH KONSUMSI TELUR AYAM RAS REBUS TERHADAP PENINGKATAN KADAR HB PADA IBU HAMIL TRIMESTER II DI BPM WILAYAH KERJA PUSKESMAS KLATEN TENGAH Sugita, Supiati, 1, 217-223.

Tambunan, D. M. (2011). Gambaran Kejadian dan Faktor-Faktor yang Berhubungan di Wilayah Kerja Puskesmas Sei Apung Kabupaten Asahan Tahun 2011. Skiripsi, 1(1), 168.

Tanziha, I., Utama, L. J., \& Rosmiati, R. (2016). Faktor Risiko Anemia Ibu Hamil Di Indonesia, 11(2), 143-152. https://doi.org/10.25182/jgp.2016.11.2.\%p

Tarwoto, W. (2015). Kebutuhan Dasar Manusia dan Proses Keperawatan. jakarta: Salemba Medika. Wiknjosastro, H. (2010). Ilmu Kebidanan. Jakarta: Yayasan Bina Pustaka Sarwono Prawirohardjo. 